\title{
FAKTOR SITUASIONAL, ORIENTASI TUJUAN, DAN LOCUS OF CONTROL SEBAGAI PREDIKTOR PRAKTEK MENYONTEK: PENYUSUNAN DAN PENGUJIAN MODEL
}

\author{
Mujahidah \\ STAIN Samarinda \\ Jl. K.H. Abul Hasan No. 3 Samarinda \\ Email: lovesamarinda@yahoo.com
}

\begin{abstract}
Abstrak:
Masalah menyontek telah menjadi persoalan krusial dalam dunia pendidikan, khususnya di perguruan tinggi. Faktor situasional, tujuan, dan locus of control adalah sebagian faktor yang dianggap mempengaruhi maraknya praktek menyontek. Berdasarkan analisis model persamaan struktural dapat disimpulkan model E lebih kuat daripada model A, Model B, Model C, dan model D. Hal tersebut diketahui berdasarkan kriteria nilai chi-square, nilai CFI, dan nilai $\mathrm{p}$ sehingga terdapat kesesuaian antara model dan data. Ketiga hipotesis minor yang diajukan diterima secara signifikan.
\end{abstract}

\begin{abstract}
:
The problem of cheating has become a crucial issue in education, especially in universities. Situational factors, objectives, and locus of control are some of the factors considered affect a lot of cheating practice. Based on the analysis of structural equation models, it can be inferred that $\mathrm{E}$ model is more powerful than the model A, Model B, Model C and Model D. It is known by the criteria of the chisquare value, the value of the CFI, and the value of $p$, therefore there is a correspondence between the model and the data. Three minor hypotheses proposed are received significantly.
\end{abstract}

\section{Kata kunci: \\ Menyontek, mahasiswa, situasional, tujuan, locus of control.}

PERILAKU menyontek merupakan fenomena yang sudah lama ada dalam dunia pendidikan. Menyontek telah menjadi permasalahan serius di beberapa perguruan. ${ }^{1}$ Praktek Menyontek (cheating atau academic cheating) adalah perbuatan curang, tidak jujur, dan tidak legal dalam mendapatkan jawaban pada saat tes-tes tertutup. Menyontek adalah suatu bentuk penipuan dengan melakukan tindakan curang yang akan memberikan keuntungan bagi pelaku penyontek tersebut. ${ }^{2}$ Dikatakan sebagai tindakan curang dan penipuan karena menyontek merupakan upaya yang dilakukan seseorang untuk mendapatkan keberhasilan dengan cara-cara yang tidak adil dan tidak jujur.

Banyak faktor yang mempengaruhi perilaku menyontek seperti usia, ${ }^{3}$ jenis kelamin, ${ }^{4}$ IPK, ${ }^{5}$ aktivitas ekstrakurikuler, ${ }^{6}$ pengaruh teman sebaya, ${ }^{7}$ kode etik, ${ }^{8}$ menunda pekerjaan, ${ }^{9}$ alat komunikasi/hp, ${ }^{10}$ status perkawinan, ${ }^{11}$ self-esteem, ${ }^{12}$ situasi pada saat ujian berlangsung/ pengawasan, ${ }^{13}$ perkembangan moral, ${ }^{14}$ rendahnya motivasi, ${ }^{15}$ dan lain-lain.

Secara formal, setiap sekolah atau institusi pendidikan lainnya telah memiliki aturan baku yang melarang para siswanya untuk menyontek. Akan tetapi, dalam 
prakteknya sangat sulit menegakkan aturan yang satu ini. Pemberian sanksi atas tindakan nyontek yang tidak tegas dan konsisten merupakan salah satu faktor maraknya praktek nyontek. ${ }^{16}$

Berbagai peneliti telah mengkaji perilaku menyontek dengan variabel-variabel yang dianggap memberikan sumbangsih. Tulisan ini mencoba mencermati praktek menyontek di perguruan tinggi dengan melihat faktor situasional (kebijakan kampus, tekanan teman, kontrol saat ujian, tekanan sosial, dan ketidaksiapan ujian), faktor tujuan menyontek (mendapatkan nilai bagus, mendapatkan hadiah, lulus, dan pengakuan dari orang-orang di sekitar lingkungan), dan faktor kepribadian dalam hal ini locus of control (eksternal dan internal).

Penyusunan dan pengujian model faktor situasional, tujuan, dan locus of control terhadap praktek menyontek lebih lanjut akan dikaji dengan pendekatan kuantitatif yang menggunakan model persamaan struktural.

\section{PENJELASAN MODEL TEORETIS}

\section{Praktek Menyontek}

Menyontek memiliki arti yang beraneka macam, akan tetapi biasanya dihubungkan dengan kehidupan sekolah, khususnya bila ada ulangan dan ujian. Menyontek berasal dari kata dasar "sontek" yang artinya "mengutip" atau "menjiplak". Kata mengutip sendiri diartikan menuliskan kembali suatu tulisan, sedangkan menjiplak diartikan menulis atau menggambar di atas kertas yang ditempelkan pada kertas yang dibawahnya bertulisan atau bergambar untuk ditiru.

Beragam usaha telah dilakukan untuk mendefinisikan perilaku menyontek. Menyontek adalah ketika ide dan materi yang sebenarnya bukan milik mahasiswa yang bersangkutan diakui sebagai hasil karyanya sendiri. ${ }^{17}$ Perilaku menyontek merupakan suatu tindakan curang yang sengaja dilakukan ketika seseorang mencari dan membutuhkan adanya pengakuan atas hasil belajarnya dari orang lain meskipun dengan cara tidak sah seperti memalsukan informasi terutama ketika dilaksanakannya evaluasi akademik. ${ }^{18}$ Menyontek berarti mengakui karya orang lain sebagai karyanya sendiri dengan cara-cara tertentu seperti menyalin karya orang lain tanpa sepengetahuan orang tersebut.

Memahami menyontek sebagai pengambilan atau permintaan bantuan yang tidak legal dalam tes. ${ }^{19}$ Menyontek sebagai bentuk perilaku moral yang menunjukkan ketidakjujuran siswa pada saat mengikuti tes. ${ }^{20}$ Menyontek sebagai perbuatan yang menggunakan cara-cara yang tidak sah untuk tujuan sah/terhormat yaitu mendapatkan keberhasilan akademis atau menghindari kegagalan akademis. ${ }^{21}$ Menyontek bisa diartikan sebagai salah satu bentuk dari budaya jalan pintas yang lebih mementingkan hasil yang ingin dicapai tanpa mau mengalami maupun memperhatikan prosesnya.

Bentuk lain dari perilaku menyontek adalah plagiat. Plagiat adalah memberikan dan menerima bantuan, ${ }^{22}$ informasi, ${ }^{23}$ yang tidak sah pada saat ujian berlangsung. Pengertian lain plagiat adalah mengambil, ${ }^{24}$ membeli, mengkopi, menggunakan dengan 
sengaja hasil pemikiran, ${ }^{25}$ metode, kalimat, ${ }^{26}$ seseorang tanpa permisi dan menganggap sebagai pemikiran sendiri.

Berdasarkan uraian di atas disimpulkan bahwa menyontek adalah tindakan yang tidak jujur yang dilakukan seseorang dalam pelaksanaan ujian ataupun menyelesaikan tugas akademis untuk mencapai tujuan tertentu. Praktek menyontek yang disoroti dalam tulisan ini adalah menyontek pada saat ujian dan menyontek pada saat mengerjakan tugas dari dosen.

\section{Faktor Situasional}

Faktor situasional semakin banyak diteliti karena mempunyai pengaruh yang cukup besar terhadap praktek menyontek. ${ }^{27}$ Ada lima faktor situasional yang diteliti dalam penelitian ini, yaitu kebijakan kampus, tekanan teman, kontrol saat ujian, tekanan sosial, dan ketidaksiapan mengikuti ujian.

Kebijakan Kampus. Salah satu kebijakan kampus yang membuat praktek menyontek semakin marak adalah masalah pemberian hukuman. Pada umumnya peneliti meyakini bahwa iklim perguruan tinggi telah mengikis pernyataan 'siapa yang menyontek akan mendapat hukuman'. Kurangnya perhatian institusi pendidikan terhadap praktek menyontek, dalam hal ini pemberian hukuman mengakibatkan praktek menyontek semakin marak. ${ }^{28}$ Hal tersebut semakin didukung oleh pengajar yang kurang berkompoten, tidak adil/pilih kasih.

Pengaruh teman sebaya. Bila dalam kelas terdapat beberapa anak yang menyontek akan mempengaruhi anak yang lain untuk menyontek juga. Pada awalnya seseorang tidak bermaksud menyontek, tetapi karena melihat temannya menyontek, maka merekapun ikut menyontek. ${ }^{29}$

Kontrol atau pengawasan selama ujian. Jika suasana pengawasan ketat, maka kecenderungan menyontek kecil, sebaliknya jika suasana pengawasan longgar, maka kecenderungan menyontek menjadi lebih besar. ${ }^{30}$ Pengawasan yang ketat akan terhambat jika jumlah mahasiswa dalam kelas saat ujian berlangsung terlalu padat. Padatnya populasi dalam satu kelas akan memudahkan mahasiswa menyontek. ${ }^{31}$ Jika kelas yang seperti ini menggunakan soal pilihan ganda akan memberikan peluang terjadinya menyontek. Pengaturan tempat duduk juga akan sangat mempengaruhi kemungkinan terjadinya menyontek. 32

Tekanan sosial untuk mendapat nilai tinggi. Mengejar nilai yang tinggi merupakan faktor pendorong bagi pelajar untuk menyontek. ${ }^{33}$ Tekanan sosial bisa bersumber dari para pendidik yang terkadang lebih menekankan pelajar untuk memperoleh nilai dan peringkat akademis daripada pemahaman materi pelajaran, ${ }^{34}$ tugas yang menumpuk sehingga tidak cukup waktu untuk mengerjakannya, ${ }^{35}$ orang tua yang ingin anaknya meraih prestasi tinggi, ada yang menyadari kemampuan anaknya tidak terlalu baik sehingga tidak terlalu menuntut nilai tinggi, tetapi tetap memberikan motivasi untuk berprestasi lebih baik, ada juga orang tua yang memahami kemampuan anaknya paspasan tetap menuntut prestasi tinggi demi gengsi dan kebanggaan, sehingga anak diamarahi jika mendapat nilai jelek. 
Ketidaksiapan mengikuti ujian. Salah satu alasan yang membuat siswa tidak siap menghadapi ujian adalah kemalasan untuk belajar secara teratur dan mempersiapkan diri sebaik mungkin. ${ }^{36}$ Selain itu, kebiasaan belajar hanya ketika mau ujian. Akibat sistem belajar yang seperti itu maka siswa tidak mampu menguasai seluruh materi yang akan diujikan secara optimal, sehingga lebih mengandalkan menyontek. Meski demikian, ada beberapa alasan mengapa seseorang tidak sempat belajar yakni status perkawinan khususnya yang sudah mempunyai anak 37 keterlibatan di organisasi membuat tidak sempat belajar karena padatnya kegiatan bekerja sambil kuliah.

\section{Faktor Tujuan}

Kompetisi memperoleh nilai dan peringkat akademis. Adanya persaingan mendapatkan nilai dan peringkat akademis merupakan salah satu faktor yang memungkinkan seseorang menyontek. ${ }^{38}$ Kaitannya dengan prestasi akademis, mahasiswa yang memperoleh nilai tinggi justru biasa menyontek untuk mempertahankan prestasinya. ${ }^{39}$ Mempertahankan prestasi akademis bisa mengangkat citra positif seseorang walaupun dilakukan dengan cara menyontek.40

Memperbaiki nilai rendah. Memperoleh nilai buruk pada ujian atau saat mengerjakan tugas pada evaluasi sebelumnya membuat seseorang menyontek untuk memperbaiki nilai tersebut. ${ }^{41}$

Tidak mau gagal. Ketika seseorang tidak mau menunda ujian karena tidak siap ujian, maka akan muncul kecemasan karena prestasi akademiknya akan terancam. Kecemasan akan kegagalan membuat seseorang melakukan jalan pintas agar tetap lulus, yaitu dengan cara menyontek. ${ }^{42}$ Salah satu sumber utama ketakutan terhadap kegagalan adalah pengalaman kegagalan pada tes-tes sebelumnya.43 Kegagalan dalam suatu tes lebih sering diikuti oleh tindakan menyontek pada tes berikutnya bila dibandingkan dengan keberhasilan. ${ }^{4}$

Kebutuhan akan pengakuan. Hasil penelitian menunjukkan bahwa seseorang dengan kebutuhan akan pengakuan tinggi lebih sering menyontek dibandingkan dengan seseorang yang tingkat kebutuhan akan pengakuannya rendah. ${ }^{45}$ Lebih jauh Lobel dan Levanon mengatakan bahwa seseorang yang butuh akan pengakuan merasa takut untuk tidak berbuat seperti yang orang lain lakukan.

\section{Locus of control}

Konsep locus of control (diistilahkan juga dengan pusat kendali) pertama kali diajukan oleh Rotter berdasarkan teori belajar sosialnya. Pada dasarnya konsep locus of control menunjukkan pada keyakinan atau harapan-harapan individu mengenai sumber penyebab dari peristiwa-peristiwa yang terjadi dalam hidupnya, yaitu kejadiankejadian yang terjadi pada dirinya dikendalikan oleh kekuatan dari dalam dirinya (internal) atau dari luar dirinya (eksternal). ${ }^{46}$ Pendapat ini diperkuat oleh Petri yang mengatakan bahwa locus of control merupakan konsep yang secara khusus berhubungan dengan harapan individu mengenai kemampuannya untuk mengendalikan penguat yang menyertai perilaku. ${ }^{47}$

Pendapat lain yang dikemukakan oleh Baron dkk. menyebutkan bahwa locus of control merupakan salah satu aspek karakteristik kepribadian yang dimiliki setiap in- 
dividu, mempengaruhi harapan dan tingkah lakunya dalam menghadapi lingkungan. Setiap perilaku manusia dipengaruhi oleh persepsi terhadap hasil yang akan dicapai, yang dapat menjadi faktor penguat atau pelemah untuk perilaku selanjutnya. Perbedaan orientasi locus of control akan mempengaruhi perbedaan dalam menghadapi peristiwa-peristiwa atau situasi yang sedang dihadapi. Perbedaan ini selanjutnya juga akan mempengaruhi perbedaan dalam sikap dan tingkah laku individu dalam menghadapi lingkungannya. ${ }^{48}$

Orang dengan locus of control eksternal punya sifat mudah cemas, depresi, dan sifat lain sejenisnya, ${ }^{49}$ besar kemungkinannya mengalami frustasi karena mudah tertekan dan kurang berhasil. Mereka yang bertipe eksternal (Powerful others dan chance locus of control) ini merasa tidak memiliki kemampuan sehingga merasa tak berdaya. 50

Menurut Weiner, individu yang mempunyai locus of control eksternal menghubungkan peristiwa-peristiwa yang terjadi, baik maupun buruk, disebabkan oleh faktor-faktor di luar dirinya, seperti kesempatan, keberuntungan, nasib, dan orang-orang lain yang berkuasa serta kondisi-kondisi yang tidak mereka kuasai. Individu yang eksternal cenderung untuk mengambil informasi baik yang berguna maupun tidak berguna, dan menyukai resiko besar maupun kecil dengan mengharapkan kepastian dan kesempatan. ${ }^{51}$

Menurut Alegre dan Murray subyek yang terkendali secara eksternal ini lebih mudah terkena bujukan melalui cara verbal-conditioning, yang tentunya menggunakan penguat dari luar dirinya. ${ }^{52}$ Mereka juga mempunyai konformitas yang lebih tinggi terhadap norma sosial. ${ }^{53}$

\section{HIPOTESIS}

Berdasarkan tinjauan teoretis yang telah diuraikan di atas, diusulkan hipotesis mayor dan hipotesis minor.

\section{Hipotesis Mayor}

Hipotesis mayor dalam penelitian ini adalah ada kesesuaian antara model teoretis dengan data faktual.

\section{Hipotesis Minor}

Hipotesis minor penelitian ini adalah:

1. Ada hubungan negatif antara faktor situasional dengan perilaku menyontek

2. Ada hubungan positif antara tujuan dengan perilaku menyontek

3. Ada hubungan negatif antara Locus of control dengan perilaku menyontek

\section{METODE}

\section{Identifikasi Variabel Penelitian}

Variabel dalam penelitian ini ada empat, tiga variabel bebas dan satu variabel terikat. Adapun variabel-variabel tersebut adalah:

Variabel bebas: 
1. Situasional

2. Tujuan

3. Locus of Control

Variabel terikat: Perilaku menyontek

\section{Definisi Operasional Variabel Penelitian}

Definisi operasional adalah definisi yang didasarkan atas sifat-sifat variabel tersebut yang dapat diamati, sehingga membuka kemungkinan bagi orang lain untuk melakukan hal yang serupa, dan dapat diuji oleh orang lain. Dengan kata lain, definisi operasional ini memberi petunjuk perincian mengenai kegiatan peneliti dalam melakukan pengukuran terhadap variabel penelitian.

Definisi operasional dari variabel-variabel dalam penelitian ini adalah:

1. Situasional

Situasional adalah kondisi yang menyebabkan seseorang memutuskan menyontek. Ada lima komponen yang diukur dalam penelitian ini, yaitu kebijakan kampus, pengaruh teman sebaya, kontrol saat ujian, tekanan sosial yang tinggi untuk mendapatkan nilai dan prestasi akademis, dan ketidaksiapan ujian.

2. Tujuan

Tujuan merupakan sesuatu yang memberikan kekuatan dan mengarahkan aktivitas. Tujuan berhubungan dengan alasan mengapa seseorang menyontek. Dalam penelitian ini terdapat empat tujuan seseorang menyontek yaitu berkompetisi demi memperoleh nilai dan prestasi akademis yang tinggi, memperbaiki nilai yang sebelumnya tidak bagus, ketakutan akan kegagalan, dan kebutuhan akan pengakuan.

3. Locus of control

Locus of control adalah keyakinan seseorang terhadap sumber-sumber yang mengendalikan kejadian-kejadian dalam hidupnya, orientasinya internal, eksternal powerful-others dan eksternal change. Besarnya keyakinan tersebut diukur dengan skala Locus of control berdasarkan teori dari Rotter yang terdiri dari dua dimensi, yaitu internal dan eksternal (skala I-E).

4. Perilaku menyontek.

Menyontek adalah tindakan yang tidak jujur yang dilakukan seseorang dalam pelaksanaan ujian ataupun menyelesaikan tugas akademis untuk mencapai tujuan.

\section{Subyek Penelitian}

Karakteristik subyek penelitian dalam penelitian ini adalah mahasiswa yang duduk pada semester dua (angkatan 2008/2009), empat (angkatan 2007/2008), dan enam (angkatan 2006/2007). Tidak dimasukkannya mahasiswa semester delapan (angkatan 2005/2006) dalam penelitian ini karena mahasiswa pada semester tersebut lebih banyak melaksanakan praktek lapangan baik PKL maupun KKN.

Dasar pertimbangan penentuan mahasiswa sebagai subyek penelitian adalah:

1. Perkembangan kognitif; mencapai puncak kematangan kognitif, daya nalar tinggi, mampu berfikir obyektif; 
2. Secara praktis mahasiswa merupakan komunitas yang tidak asing lagi yang namanya penelitian sehingga diharapkan nantinya mereka akan kooperatif di dalam berpartisipasi dalam penelitian ini.

\section{Alat Pengumpul Data}

Alat pengumpul data yang digunakan dalam penelitian ini adalah

\section{Situasional}

Faktor situasional diungkap dengan alat ukur yang disusun oleh McCabe dkk., dengan mengurangi dan menambahkan dimensi. Adapun dimensi hasil modifikasi adalah kebijakan kampus, kontrol saat ujian, tekanan teman, tekanan sosial dan ketidaksiapan mengikuti ujian.

\section{Tujuan}

Angket yang digunakan untuk mengukur tujuan adalah PALS yang disusun oleh Midgley dkk. Akan tetapi angket tersebut akan dimodifikasi sehingga menjadi empat indikator, yaitu ingin berkompetisi, memperbaiki nilai, tidak mau gagal dalam ujian serta kebutuhan akan pengakuan.

\section{Locus of control}

Locus of control diukur dengan skala yang disusun berdasarkan teori dari Rotter yang terdiri dari dua dimensi, yaitu internal dan eksternal (skala I-E)

4. Perilaku menyontek

Perilaku menyontek diukur dengan menggunakan skala Balanced Inventory of Desirable Responding (BIRD) yang disusun oleh Paulus (2000) yang terdiri dari 20 item.

\section{Model Hipotesis}

Model Hipotesis dalam penelitian ini terdiri dari empat variabel laten dan tiga belas variabel observed. Model hipotesis dapat dilihat pada gambar 1 di bawah ini:

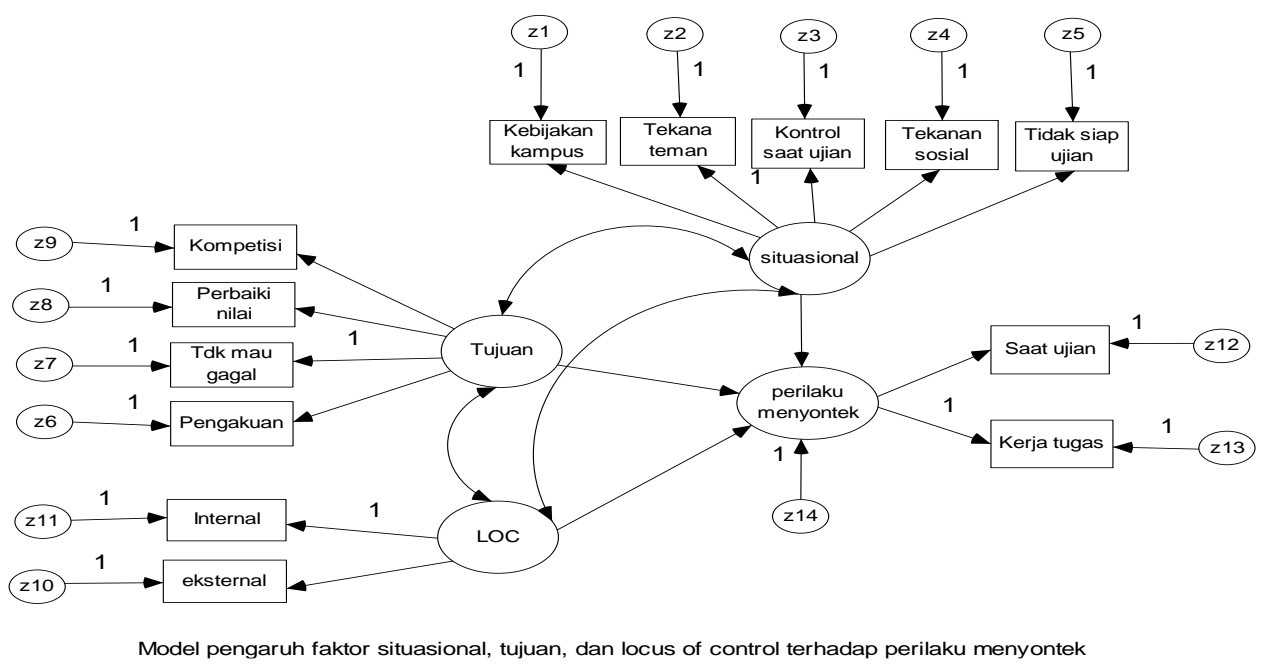

Gambar 1 


\section{HASIL DAN PEMBAHASAN}

\section{Uji model : Hasil Analisis dan Modifikasi}

Untuk menguji model persamaan struktural penulis menggunakan program AMOS versi 6 . Kesesuaian menyeluruh yaitu ukuran mengenai kesesuaian model yang dirancang dengan data yang diperoleh secara keseluruhan akan dilihat melalui indeks fit. ${ }^{54}$ Adapun Kriteria pengujian kecocokan model adalah sebagai berikut :

1. Chi-square, model dikatakan cocok apabila hipotesis nol dalam chi-square terbukti, karena berarti tidak ada perbedaan antara model yang dirancang dengan data. Chisquare diharapkan kecil.

2. GFI (Goodness of Fit Index), yang bergerak antara 0 sampai dengan 1, semakin mendekati 1 berarti model makin sesuai.

3. AGFI (Adjusted Goodness of Fit Index), yang memperhitungkan derajat kebebasan dalam pengujian model. Tolak ukur AGFI sama dengan GFI.

4. RMSEA (Root Mean Square Error of Approximation), adalah yang menggambarkan ketepatan model yang dapat diharapkan jika model tersebut diestimasi dalam populasi. Indikasi kesesuaian model adalah 0 sampai dengan 0,05 .

5. TLI (Tucker Lewis Index), adalah sebuah alternatif incremental fit index yang membandingkan sebuah model yang diuji terhadap sebuah baseline model. Nilai yang direkomendasikan sebagai acuan untuk diterimanya suatu model adalah $\geq 0.95$

6. CFI (Comparative Fit Index), besarnya index ini berada pada rentang nilai 0-1.

\section{Hasil Analisis}

Berdasarkan hasil analisis model persamaan struktural untuk model faktor situasional, tujuan, dan locus of control diperoleh nilai chi-square sebesar 87.1, $\mathrm{db}=59$, dan $p=0,010$, nilai GFI sebesar 0.968 dan nilai sebesar AGFI 0.951. Hasil analisis menunjukkan nilai $\mathrm{p}$ masih kurang dari 0.05. Oleh karena itu dipakai kriteria pengujian kecocokan model RMSEA, TLI dan CFI. Berdasarkan hasil analisis diperoleh nilai RMSEA=0,035, TLI=0,947, CFI=0,960. Berdasarkan nilai RMSEA model ini masih dapat diterima tetapi nilai TLI masih dibawah 0,95, untuk itu model yang diuji dapat ditingkatkan dengan modifikasi. Hasil analisis model A dapat dilihat di bawah ini:

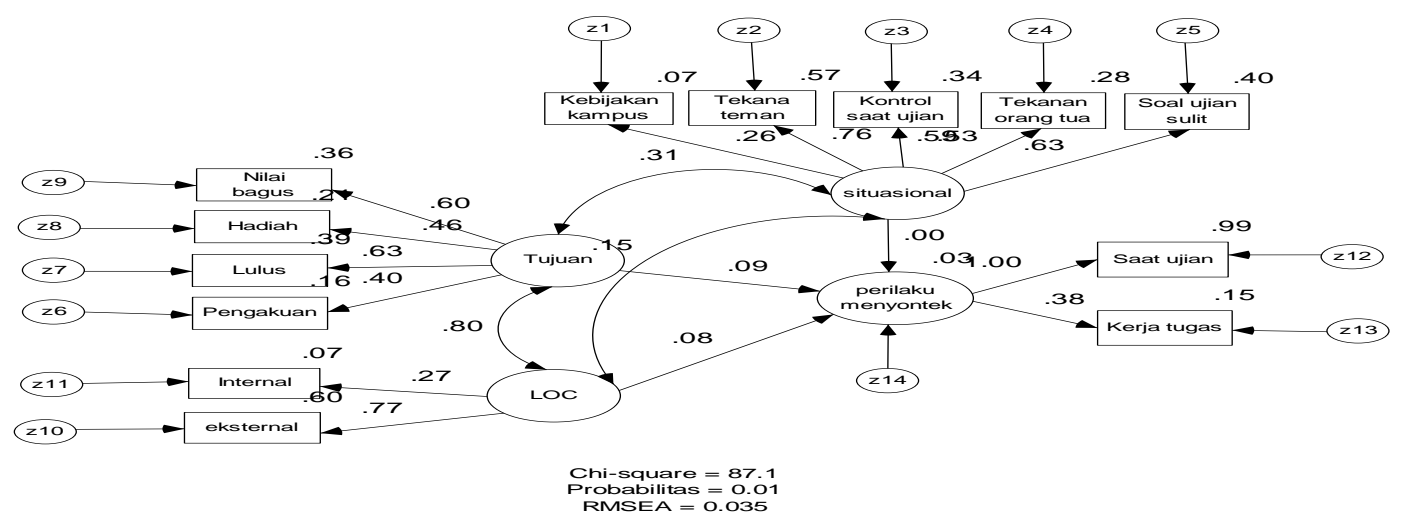

Gambar 2. Model A 


\section{Modifikasi 1.}

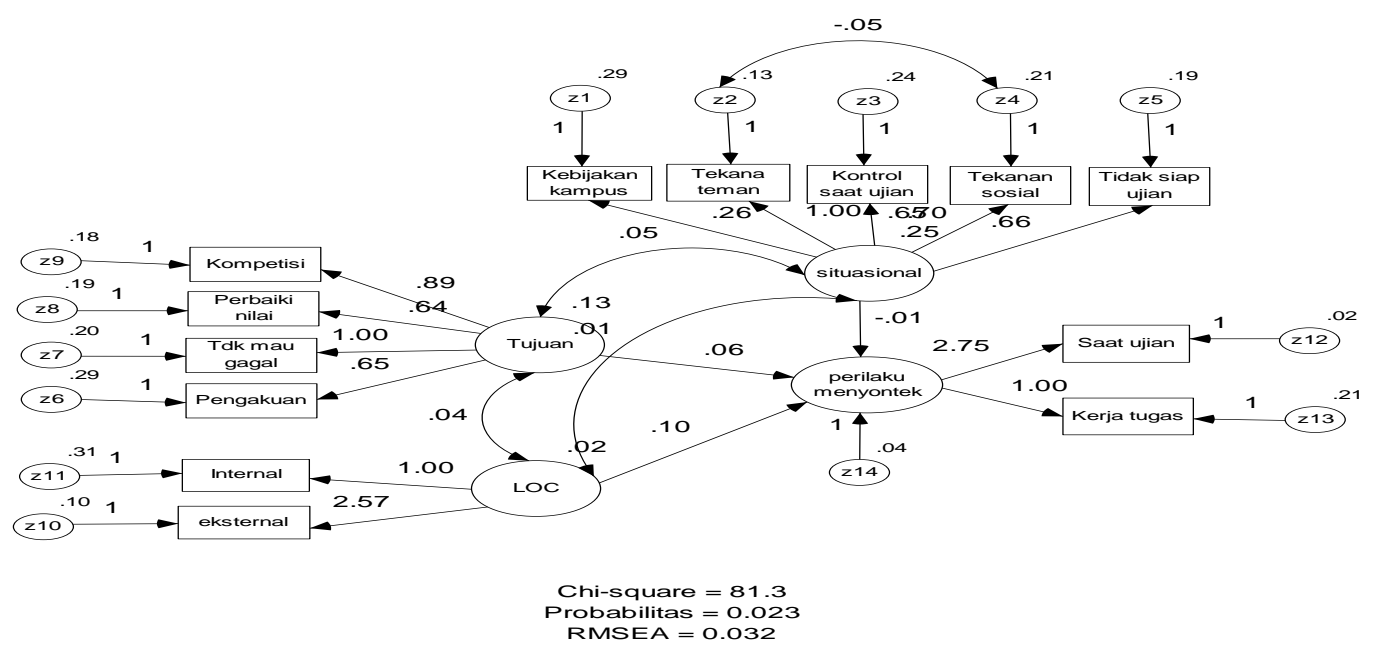

\section{Gambar 3. Hasil Modifikasi Pertama (Model B)}

Analisis pada model B di atas, dilakukan korelasi antar kesalahan pengukuran indikator (error measurement). Hal tersebut dilakukan dengan mengamati variabel faktor situasional yang diduga ada korelasi antar kesalahan pengukuran indikator pada indikator tekanan teman dan tekanan sosial.

Setelah dilakukan analisis model persamaan struktural terhadap model B (gambar 3), diperoleh nilai chi-square sebesar 81.3, $d b=58$,dan $p=0,009$, RMSEA=0,032, $\mathrm{TLI}=0,955, \mathrm{CFI}=0,966$. Berdasarkan nilai RMSEA model ini masih dapat diterima tetapi nilai probablitasnya masih dibawah 0,05 , karenanya model tersebut masih dapat diuji dengan meningkatkan melalui modifikasi kedua (berdasarkan Model A dan B).

\section{Modifikasi 2.}

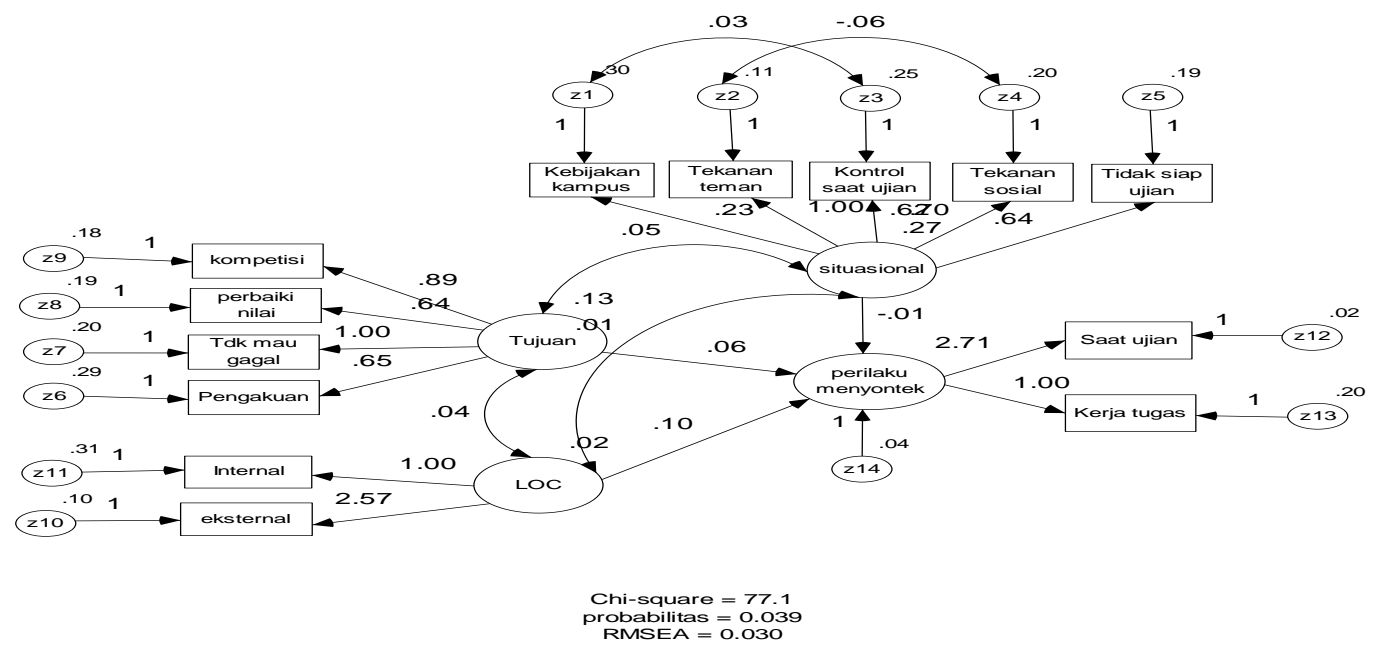

Gambar 4. Hasil Modifikasi Kedua (Model C) 
Pada model C di atas, dilakukan korelasi antar kesalahan pengukuran indikator (error measurement). Masih mengamati variabel faktor situasional, diduga ada korelasi antar kesalahan pengukuran indikator pada indikator kebijakan kampus dan kontrol saat ujian.

Setelah dilakukan analisis model persamaan struktural terhadap model C (gambar 3), diperoleh nilai chi-square sebesar 77.1, $d b=57$, dan $p=0,039$, RMSEA=0,030, $\mathrm{TLI}=0,960, \mathrm{CFI}=0,971$. Berdasarkan nilai RMSEA model ini masih dapat diterima.

Berdasarkan hasil pengujian terhadap C, dengan memperhatikan nilai RMSEA, model tersebut masih bisa diterima. Meski demikian, nilai probabilitasnya masih dibawah 0,05 , karenanya model tersebut masih dapat diuji dengan meningkatkan melalui modifikasi ketiga (berdasarkan Model A, B, dan C).

\section{Modifikasi 3}

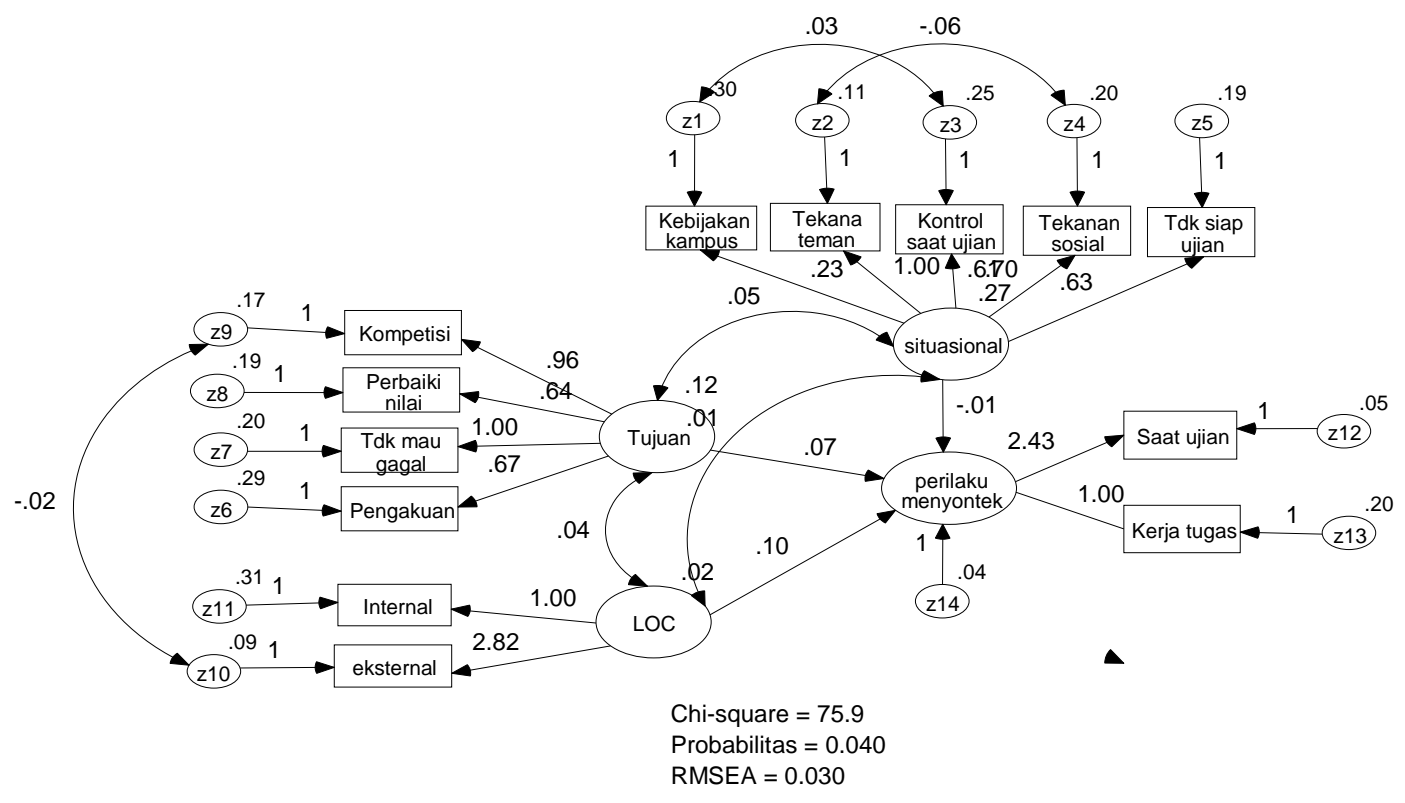

\section{Gambar 5. Hasil Modifikasi ketiga (Model D)}

Analisis pada model D di atas, dilakukan korelasi antar kesalahan pengukuran indikator (error measurement). Hal tersebut dilakukan dengan mengamati variabel faktor tujuan dan locus of control yang diduga ada korelasi antar kesalahan pengukuran indikator pada indikator kompetisi dan locus of control eksternal.

Setelah dilakukan analisis model persamaan struktural terhadap model D (gambar 5), diperoleh nilai chi-square sebesar 75.9, $\mathrm{db}=56$, dan $\mathrm{p}=0,040, \mathrm{RMSEA}=0,030$, $\mathrm{TLI}=0,960, \mathrm{CFI}=0,971$ (hasil selengkapnya dapat dilihat pada lampiran). Berdasarkan nilai RMSEA model ini masih dapat diterima tetapi nilai probablitasnya masih di bawah 0,05, karenanya model tersebut masih dapat diuji dengan meningkatkan melalui modifikasi keempat (berdasarkan Model A, B, C, dan D). 


\section{Modifikasi 4}

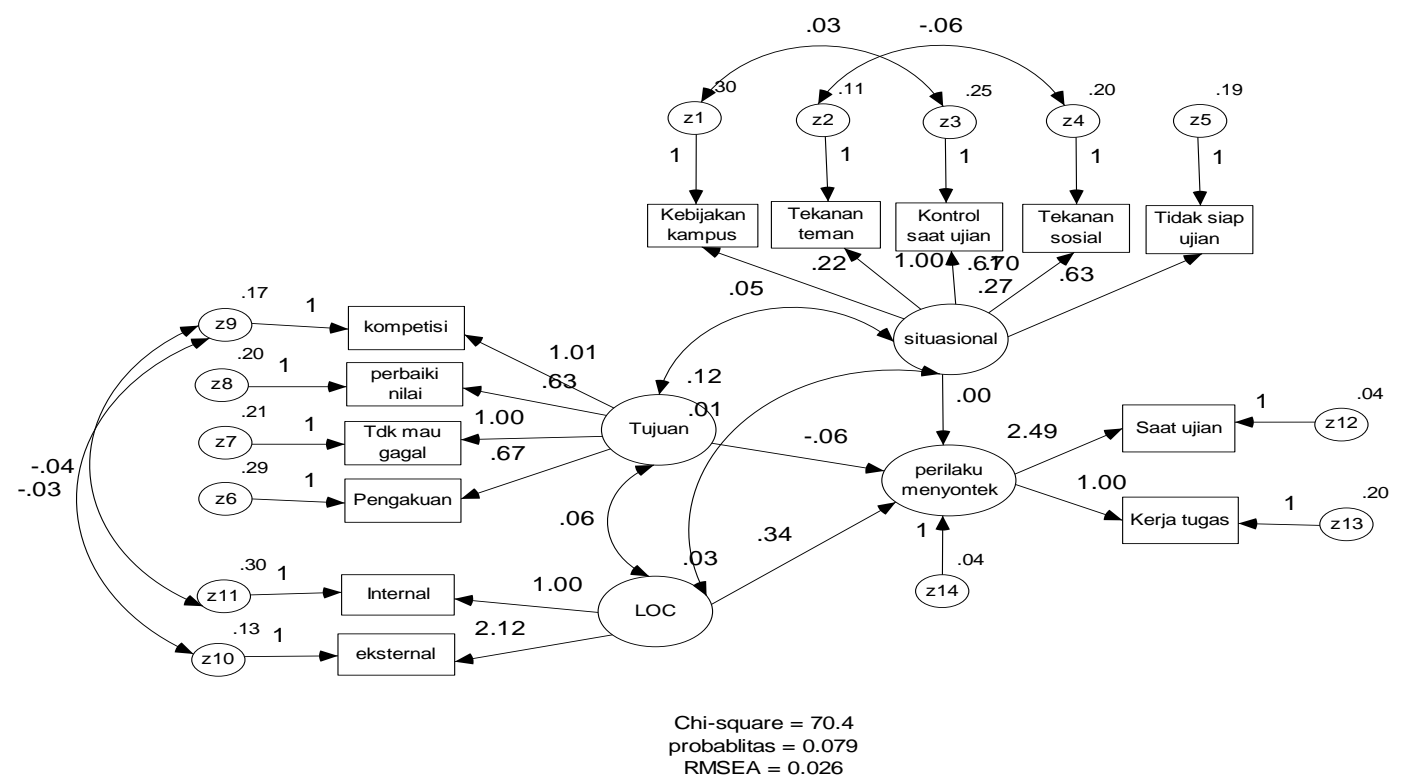

\section{Gambar 6. Hasil Modifikasi keempat (Model E)}

Analisis pada model D di atas, dilakukan korelasi antar kesalahan pengukuran indikator (error measurement). Hal tersebut dilakukan dengan mengamati variabel faktor tujuan dan locus of control yang diduga ada korelasi antar kesalahan pengukuran indikator pada indikator nilai bagus dan locus of control eksternal.

Setelah dilakukan analisis model persamaan struktural terhadap model E (gambar ), diperoleh nilai chi-square sebesar 70.4, $\mathrm{db}=55$,dan $\mathrm{p}=0,079, \mathrm{RMSEA}=0,026, \mathrm{TLI}=0$, 969, CFI=0,978.

Berdasarkan hasil pengujian terhadap Model A, Model B, Model C, Model D, dan Model E yang didasarkan pada nilai RMSEA, GFI, TLI, CFI, dan probabilitas kelima model tersebut menunjukkan indikasi kesesuaian model. Oleh karena itu ketiga model tersebut akan dibandingkan untuk menentukan model yang lebih sesuai.

Ada berbagai cara untuk membandingkan alternatif model. Pertama: dapat dilihat dari besarnya nilai chi-square dan model yang lebih kuat ditunjukkan oleh nilai chi-square yang lebih kecil. Model yang diuji dipandang baik bila nilai chi-squarenya rendah, semakin kecil nilai chi-square semakin baik model itu. Berdasarkan kriteria tersebut, model $\mathrm{E}$ lebih dapat diterima daripada model $\mathrm{A}$, model $\mathrm{B}$, model $\mathrm{C}$, dan model D (Model A: nilai chi-square $=87,1$; model B: nilai chi-square $=81,3$; model C: nilai chi-square $=77,1$; model D: nilai chi-square $=75,9$; dan model E: nilai chi-square $=$ $70,4) .55$

Cara lain adalah dengan membandingkan CFI (Comparative Fit Index). ${ }^{56}$ Nilai CFI model yang lebih tinggi, menunjukkan model tersebut lebih baik. Berdasarkan kriteria ini, model $\mathrm{E}$ lebih dapat diterima daripada model $\mathrm{A}$, model $\mathrm{B}$, model $\mathrm{C}$, dan model D. CFI model A =0,960, CFI model $\mathrm{B}=0,966$, CFI model $\mathrm{C}=0,971$, CFI model $\mathrm{D}=0,971$ dan $\mathrm{CFI}$ model $\mathrm{E}=0,978$. 


\section{Pembahasan Model Hipotesis}

\section{Hipotesis mayor}

Hipotesis mayor penelitian ini adalah adalah ada kesesuaian antara model teoretis dengan data faktual. Berdasarkan hasil analisis model persamaan struktural terhadap model $\mathrm{E}$ (gambar 6), diperoleh nilai chi-square sebesar 70,4 $\mathrm{db}=55$, dan $p=0,079$, RMSEA $=0,026$, TLI $=0,969, \mathrm{CFI}=0,979$. Berdasarkan nilai RMSEA, nilai chisquare yang lebih kecil, model $\mathrm{E}$ lebih dapat diterima daripada model A, model B, model C atau model D.

\section{Hipotesis Minor}

Hipotesis minor penelitian ini adalah

1. Ada hubungan negatif antara faktor situasional dengan perilaku menyontek ( $\mathrm{p}=0.000, \mathrm{p} \leq 0.05$, hipotesis diterima).

2. Ada hubungan positif antara tujuan dengan perilaku menyontek $(p=0.000, p \leq 0.05$, hipotesis diterima)

3. Ada hubungan negatif antara Locus of control dengan perilaku menyontek $(\mathrm{p}=0.029$, $\mathrm{p} \leq 0.05$, hipotesis diterima)

\section{SIMPULAN}

Berdasarkan analisis model persamaan struktural dapat disimpulkan model E lebih kuat daripada model A, model B, model C dan model D dilihat dari besarnya nilai chi-square, nilai CFI dan nilai P. Ketiga hipotesis minor yang diajukan diterima secara signifikan.

\section{CATATAN AKHIR}

1. A. Franklyn-Stokes \& S. Newstead, Undergraduate cheating: Who does what ang why? Studies in Higher Education, 20, 1995, h. 159-172; D.L. McCabe \& L.K. Trevino, Individual and contextual influences on academic dishonesty: A multi campus investigation, Research in Higher Education, 38, 1997, h. 379-396; K.V. Finn \& M.R. Frone, Academic performance and cheating: moderating role of school identification and self-efficacy, The Journal of Educational Research, 97, 2004, h. 115-162; N.W. Pino \& W.L. Smith, College Student \& Academic Dishonesty, College Student Journal, 490-500, 2004. Diambil dari http://www.swarthmore.eduNatSci/cpurrin1/plagiarism/docs/PinoandSmith2003. pdf. Diakses pada tanggal 18 Oktober 2008.

2. J. Athanasou \& Olasehinde, Male and Female Differences in Self-report Cheating, Journal Practical Assessment, Researh and Evaluation, VIII, 2002, h. 1-13.

3. Ibid; L.L. Schwartz \& Stowe. An analisis of cheating among business student: The influence of religion and the champus environment, 2006, Diambil dari http://abe.villanova.edu/proc2006/ schwartz.pdf. Diakses pada tanggal 18 Oktober 2008; Ibid.

4. D. A. Becker \& I. Ulstad, Gender Differences in students ethics: are female really more ethical? Plagiarsm Disciplinary Studies in Plagiarism, Fabrication, and Falsification, 2, 2007, h. 1-15.

5. Ibid.

6. Ibid.

7. D. Teodorescu \& T. Andrei, Faculty and peers influences on academic integrity: College cheating in Romania, Journal of Higher education, 3, 2008, h. 1-12. 
8. T.S. Harding, D.D. Carpenter, C.J. Finelli \& H.J. Passow, Does Academic dishonesty related to unethical behavior in professional practice? An exploratory study, Science and Engineering Study, 10, 2004, h. 311-324.

9. Pino \& Smith, op.cit.

10. E.S. Levy \& C.C. Rakovski, Academic dishonesty: A Zero Tolerance Professor and Student Registration Choices. Research in Higher Education, 47, 2006, h. 735-754

11. D.C. Atkins, D.H. Baucom \& N.S. Jacobson, Understanding infidelity: Correlates in a national random sample, Journal of Family Psychology, 15, 2001, h. 735-749.

12. S.M. Drigotas, C.A. Safstrom \& T. Gentilia, An investment model prediction of dating infidelity, Journal of Personality and Social Psychology, 77, 1999, h. 509-524.

13. G.M. Lucas \& J. Friedrich, Individual differences in workplace deviance and integrity of predicttors of academic dishonesty, Ethics \& Behavior, 15, 2005, h. 15-35; Levy \& Rakovski, op. cit.

14. M.A. Graham, J. Monday, K. O'Brien \& S. Steffen, Cheating at small colleges: An examination student and faculty attitudes and behavior, Journal of College Student Development, 35, 1994 h. 255-260; R.A. Bernardi, R.L. Metzger, R.S. Bruno, M.W. Hoogkamp, L.E. Reyes, \& G.H. Barnaby, Examining the decision process of students' cheating behavior: an empirical study. Journal of Business Ethics, 50, 2004, h. 397-414.

15. D.C. Barnett, and J. C. Dalton, 'Why college students cheat', Journal of College Student Personnel, 22, 1981, h. 545-551.

16. S.F. Davis, C.A. Grover, A.H. Becker \& L.N. McGregor, Academic dishonesty: Prevalence, determinants, techniques, and punishment, Teaching of Psychology, 19, 1992, h. 16-20; M.J. Clement, Academic dishonesty: To be or not to be? Journal of Criminal Justice Education, 12, 2001, h. 253-270; Pino \& Smith, op.cit. ; Levy \& Rakovski, op. cit. ; M. Vandehey, G.M. Diekhoff, \& E.E. Labeff, College cheating: A twenty-years follow up and the addition of an honor code, Journal of college Students Development, 8, 2007; Teodorescu \& Andrei, op. cit.

17. J.R. Godfrey, R.F. Waugh, E.D. Evans, \& D. Craig, Measuring Student Perception About Cheating: A Cross-cultural comparison, Australia Journal Psychology, 47, 1994, h. 73-80.

18. L.P. Pincus, \& Schemelkin, Faculty perception of academic dishonesty: A multidimensional scaling analysis, Journal of Higher Education, 74, 2003, h. 196-203.

19. H.D. Thornberg, Development in Adolesence, California: Wadsworth, 1982.

20. R.S. Peters, Moral Development and Moral Education, London: George Allen and Unwin, Ltd, 1981.

21. W.J. Bower, Student dishonesty and its control in college. New York: Bureau of Applied Social Research, Columbia University, 1961.

22. W.L. Kibler, Academic dishonesty: A student development dilemma. NASPA Journal, 30, 1993, h. 253-262.

23. P.L. Ehrenkranz, To cheat or no to cheat, Listen Hagerstown, 55, 2001, h. 12-14.

24. L.A. Clyde, Electronic plagiarism. Teacher Librarian, 29, 2001, p. 32-58; L.B. Zulle, J. Azman, V. Frkovic, \& M. Petrovecki, Is there an effective approach to deterring students from plagiarizing? Science Engineering Ethics, 14, 2008, h. 193-147.

25. Ibid; Ibid.

26. Ibid.

27. D.L. McCabe, T. Feghali, \& H. Abdallah, Academic dishonesty in the middle east: Individual and contextual factors, Research Higher Education, 49, 2008, h. 451-467.

28. Lucas \& friedrich, op. cit. ; Levy \& Rakovski, op. cit.; C.H.S. Lin \& L.M. We, Academic dishonesty in higher education-a nationwide study in Taiwan, Higher Educational Journal, 54, 2007, h. 85-97.

29. S.R. Burns, S.F. Davis, J. Hoshino, R.L. Miller, Academic dishonesty: A delineation of crosscultural patterns, College Students Journal, 32, 1988, h. 590-597; D.L. McCabe, \& L.K. Trevino, Individual and contextual influences on academic dishonesty: A multi campus investigation, 
Research in Higher Education, 38, 1997, p. 379-396; Pino \& Smith, op, cit. ; Teodorescu \& Andrei, op. cit. ; McCabe et al, op. cit.

30. C.A. Caroli, Cheating is pervasive problem in education: forum participants say, Education Week, 23, 2004, h. 10; Lucas \& friedrich, op. cit.; Levy \& Rakovski, op. cit.; Zulle et al, op. cit.

31. Burn et al, op. cit. ; Lim \& Wen, op. cit.

32. Ibid; L. Nath \& M. Lavaglia, Cheating on multiple-choice exams: Monitoring, assessment, and an optimal assignment, College Chating, 57, 2008, h. 1-8.

33. S.E. Newstead, A.F. Stokes \& P. Armstead, Individual differences in student cheating, Journal of Educational Psychology, 88, 1996, h. 229-241 ; Harding et al, op. cit.; D.L. McCabe, L.K. Treviño, \& K.D. Butterfield, Cheating in academic institutions: A decade of research, Ethics and Behavior, 11, 2001, h. 219-232; K.V. Finn, \& Frone, op. cit.; E.G. Lambart, N.G. Hogan, \& S.M. Barton, Colligiate academic dishoneaty revisited: What have they done, how often have they done it,, who does it, and why they do it? Electronic Journal of Sociology, 74, 2004, h. 234-146.

34. S.F. Davis, C.A. Grover, A.H. Becker, \& L.N. McGregor, Academic dishonesty: Prevalence, determinants, techniques, and punishment, Teaching of Psychology, 19, 1992, h. 16-20; G.J. Cizek, Cheating on test, how to do it, detect it, and prevent it, Mahwah, New Jersey: Lawrence Erlbaum, 1999.

35. B.E. Witley, Factors associated with cheating among college student: A review, Research in Higher Education, 39, 1998, h. 235-274.

36. Nath \& Lavaglina, op. cit.

37. T.S. Harding, D.D. Carpenter, S.M. Montgomery \& N. Steneck, P.A.C.E.S.-A study on academic integrity among engineering undergraduates (preliminary conclusions), American Society For Engineering Education, 2002, h. 1-15.

38. Burn et al, op. cit.; C.A. Caroli, Cheating is pervasive problem in education: forum participants say, Education Week, 23, 2004, h. 10.

39. Lambert, op. cit.

40. Cizek, op. cit.; R.D. Parson, S.L. Hinson \& D. Sardo-Brown, Education psychology: A practitioner-research model of teaching, Australia: Wadsworth publishing company, 2001.

41. Burn et al, op. cit.

42. Cizek, op. cit.

43. Ibid

44. J.P. Houston, Curve linear relationship among anticipated success, cheating behavior, temptation to cheat, and perceived instrumentality of cheating, Journal of Educational Psychology, 70, 1987, p. 758-762; J.R. Godfrey, R.F. Waugh, E.D. Evans \& D. Craig, Measuring Student Perception About Cheating: A Cross-cultural comparison, Australia Journal Psychology, 47, 1994, h. 73-80.

45. T. Lobel \& H. Levanon, Self-esteem, Need for Approval and Cheating Behavior in Children, Journal of Educational Psychology, 80, 1988, h. 122-123.

46. J. Jung, Understunding Human Motivation, New York: Macmillam Publishing, Co., Inc, 1978.

47. H.L. Petri, Motivation; Theory and Research, California: Wadsworth Publishing, Co, 1980.

48. R. A. Baron, D. Byrne \& B.H. Kantowitz, Psychology Understunding Behavior, Japan: Holtz, Rinehart and Winston, 1980.

49. E.J. Phares, Locus of Control of Personality, USA: Silver Burdett Company, 1976 ; Lefcourt, HM, Locus of Control; Current Trends in Theory and Research, New Jersey: Lawrence Erlbaum Associates, Publisher, 1982; V. Molinari \& P. Khana, Locus of Control and Its Relationship to Anxiety and Depression, Journal of Personality Assesment, 3, 1981, h. 314-318.

50. Jung, op. cit.

51. R.J. Corsiny, Current Personality Theories, Illinois: F.E. Peacokck Publisher, Inc, 1977. 
52. Ibid.

53. R.H. Coop \& K.W. White, Psychological Concept in Class Room, New York: Harper \& Row, 1974.

54. G.M. Maruyama, Basic of Structural Equation Modeling, New Delhi: Sage Publication, 1998.

55. J.L. Arbuckle, AMOS 16.0 User`s Guide, USA: Amos Development corporation, 1995.

56. Maruyama, op. cit.

\section{DAFTAR PUSTAKA}

Arbuckle,J.L., AMOS 16.0 User`s Guide. USA: Amos Development corporation, 1995.

Athanasou, J. \& Olasehinde, O. Male and female differences in self-report cheating. JournalPractical Assessment, Researh and Evaluation, VIII, 1-13, 2002.

Atkins, D. C., Baucom, D. H. \& Jacobson, N. S. Understanding Infidelity: Correlates in a national random sample. Journal of Family Psychology, 15, 735-749, 2001.

Baron, R.A., Byrne, D. \& Kantowitz, B.H. Psychology Understunding Behavior. Japan: Holtz, Rinehart and Winston, 1980.

Barnett, D. C. and J. C. Dalton. 'Why college students cheat', Journal of College Student Personnel, 22, 545-551, 1981.

Bernardi, R. A., Metzger, R.L., Bruno, R.S., Hoogkamp, M.W., Reyes, L.E. \& Barnaby, G.H. Examining the decision process of students' cheating behavior: an empirical study. Journal of Business Ethics, 50, 397-414, 2004.

Becker, D.A. \& Ulstad, I. Gender Differences in students ethics: are female really more ethical? Plagiarsm Disciplinary Studies in Plagiarism, Fabrication, and Falsification, 2: 1-15, 20017.

Bower, W.J. Student dishonesty and its control in college. New York: Bureau of Applied Social Research, Columbia University, 1961.

Burns, S.R., Davis, S.F,. Hoshino, J., Miller, R.L. Academic Dishonesty: A Delineation of CrossCultural Patterns. College Students Journal, 32, 590-597, 1988.

Caroli, C.A. "Cheating is Pervasive Problem in Education: Forum Participants Say." Education Week, 23, 10, 2004.

Cizek, G,J. Cheating on test, how to do it, detect it, and prevent it. Mahwah. New Jersey: Lawrence Erlbaum, 1999.

Coop, R.H. \& White, K. W. Psychological Concept in Class Room. New York: Harper \& Row, 1974.

Corsiny, R.J. Current Personality Theories. Illinois: F.E. Peacokck Publisher, Inc., 1977.

Clement, M. J. Academic dishonesty: To be or not to be? Journal of Criminal Justice Education, 12, 253-270, 2001.

Clyde, L.A. Electronic plagiarism. Teacher Librarian, 29, 32-58, 2001.

Davis, S.F., Grover, C.A., Becker, A.H., \& McGregor, L.N. Academic dishonesty: Prevalence, determinants, techniques, and punishment. Teaching of Psychology, 19, 16-20, 1992.

Depaulo, B.M., Kashi, D.A., Kirendol, S.E., Whyer, M.M., \& Epstein, J.A. “Lying in Everiday Life." Journal of Personality and Social Psycholog\$y, 70, 979-995, 1996.

Drigotas, S. M., Safstrom, C. A., \& Gentilia, T. “An Investment Model Prediction of Dating Infidelity." Journal of Personality and Social Psychology, 77, 509-524, 1999.

Ehrenkranz, P.L. “To Cheat or No to Cheat.” Listen Hagerstown, 55, 12-14, 2001.

Finn, K.V. \& Frone, M.R. "Academic Performance and Cheating: Moderating Role of School Identification and Self-efficacy." The Journal of Educational Research, 97, 115-162, 2004.

Franklyn-Stokes, A. \& Newstead, S. "Undergraduate Cheating: Who does what ang why?" Studies in Hihger Education, 20, 159-172, 1995. 
Godfrey, J.R., Waugh, R.F., Evans, E.D. \& Craig, D. "Measuring Student Perception About Cheating: A Cross-cultural Comparison." Australia Journal Psychology, 47, 73-80, 1994.

Gomez, D. S. "Putting the Shame Back in Student Cheating." The Virginia Journal of Education, 94, 6-10, 2001.

Graham, M.A., Monday, J., O'Brien, K. \& Steffen, S. “Cheating at small colleges: An Examination Student and Faculty Attitudes and Behavior." Journal of College Student Development, 35, 255-260, 1994.

Harding, T.S., Carpenter, D.D., Finelli, C.J., \& Passow, H.J. “Does Academic Dishonesty Related to Unethical Behavior in Professional Practice? An exploratory study." Science and Engineering Study, 10, 311-324, 2004.

Harding, T.S., Carperter, D.D., Montgomery, S.M. \& Steneck, N., P.A.C.E.S. "A study on academic integrity among engineering undergraduates (preliminary conclusions)." American Society For Engineering Education. 1-15, 2002.

Hunter, J.E., \& Schmidt, F.L. Methods of Meta Analysis: Correcting Error and Bias in Research Findings. Newbury Park, California: Sage Publications.Inc., 1990.

Houston, J.P. "Curve Linear Relationship among Anticipated Success, Cheating Behavior, Temptation to Cheat, and Perceived Instrumentality of Cheating." Journal of Educational Psychology, 70. 758-762, 1987.

Hyde, J.S. “The gender similarities hypothesis.” Americant Psychologist, 60, 581-592, 2005.

Jung, J. Understunding Human Motivation. New York: Macmillam Publishing, Co., Inc., 1978.

Kaufman, H.E. "Moral and Ethical Issues Related to Academic Dishonesty on College Campuses." Journal of College \& Character, 5, 1-8, 2008.

Kibler, W.L. "Academic Dishonesty: A Student Development Dilemma." NASPA Journal, 30, 253-262, 1993.

Lambart, E.G., Hogan, N.G. \& Barton, S.M. “Colligiate Academic Dishoneaty Revisited: What Have They Done, How Often Have They Done It, Who Does It, and Why They Do It?" Electronic Journal of Sociology, 74, 234-146, 2004.

Lefcourt, HM., Locus of Control; Current Trends in Theory and Research. New Jersey: Lawrence Erlbaum Associate s, Publisher, 1982.

Levy, E.S. \& Rakovski, C.C., Academic dishonesty: A Zero Tolerance Professor and Student Registration Choices. Research in Higher Education, 47, 735-754, 2006.

Lin, C.H.S. \& We, L.M., Academic dishonesty in higher education-a nationwide study in Taiwan. Higher Educational Journal, 54, 85-97, 2007.

Lim dan See., Attitude toward, and intentions to report: Academic cheating among students in Singapore. Ethics and Behavior Journal, 11, 261-275, 2001.

Liu, X. \& Kaplan, H., Gender-related differences in circumstances surrounding initiation and esclation of alcohol and other subtance useiabuse. Deviant Behavior, 17, 71-106, 1996.

Lucas, G. M., \& Friedrich, J., Individual differences in workplace deviance and integrity of predictors of academic dishonesty. Ethics \& Behavior, 15, 15-35, 2005.

Lobel, T. \& Levanon, H., Self-esteem, Need for Approval and Cheating Behavior in Children. Journal of Educational Psychology, 80, 122-123, 1988.

Maruyama,G.M., Basic of Structural Equation Modeling. New Delhi: Sage Publication, 1998.

Murdock, T.B., Hale, N.M., \& Weber, M.J., Predictor of cheating among early among adolescent: Academic and social motivation. Contemporary Educational Psychology, 26, 96-115, 2001.

Molinari, V. \& Khana, P., Locus of Control and Its Relationship to Anxiety and Depression. Journal of Personality Assesment, 3, 314-318, 1981.

McCabe, D. L., and Trevino, L. K., Academic dishonesty: Honor codes and other contextual influences. Journal of Higher Education, 64. 522-538, 1993. 
McCabe, D.L. \& Trevino, L.K., What we know about cheating in college. Change, January/February, 23-33, 1996.

McCabe, D.L. \& Trevino, L.K., Individual and contextual influences on academic dishonesty: A multi campus investigation. Research in Higher Education, 38, 379-396, 1997.

McCabe, D. L., and Pavela, G., Some good news about academic integrity. Change, 32. 32-38, 2000.

McCabe, D.L., Treviño, L.K. \& Butterfield, K.D., Cheating in academic institutions: A decade of research. Ethics and Behavior, 11, 219-232, 2001.

McCabe, D. L., and Trevino, L. K., Honesty and honor codes. Academe 88(1): 37 -41, 2002.

McCabe, D.L., Feghali, T. \& Abdallah, H., Academic dishonesty in the middle east: Individual and contextual factors. Research Higher Education, 49, 451-467, 2008.

Newstead, S.E., Stokes, A.F. \& Armstead, P., Individual differences in student cheating. Journal of Educational Psychology, 88, 229-241, 1996.

Nath, L. \& Lavaglia, M., Cheating on multiple-choice exams: Monitoring, assessment, and an optimal assignment. College Chating, 57, 1-8, 2008.

Nuss, E. M., Academic integrity: Comparing faculty and student attitudes. Improving College and University Teaching, 32. 140-144, 1984.

Parson, R.D., Hinson, S.L. \& Sardo-Brown, D., Education psychology: A practitioner-research model of teaching. Australia: Wadsworth publishing company, 2001.

Peters, R.S., Moral Development and Moral Education. London: George Allen and Unwin, Ltd., 1981.

Petri, H.L., Motivation; Theory and Research. California: Wadsworth Publishing, Co., 1980.

Pino, N.W. \& Smith, W.L. (2004). College Student \& Academic Dishonesty. College Student Journal, 490-500. Diambil dari http://www.swarthmore.eduNatSci/cpurrin1/plagiarism/docs/PinoandSmith2003. pdf. Diakses pada tanggal 18 Oktober 2008

Pincus, L.P. \& Schemelkin, Faculty perception of academic dishonesty: A multidimensional scaling analysis. Journal of Higher Education, 74, 196-203, 2003.

Phares, E.J., Locus of Control of Personality. USA: Silver Burdett Company, 1976.

Ercegovac, Z \& Richardson, J.V., Academic dishonesty, plagiarism included, in the digital age: A literature review. College and Research Libraries, 7, 301-318, 2004.

Schwartz, L.L. \& Stowe. (2006). An analisis of cheating among business student: The influence of religion and the champus environment. Diambil dari http://abe.villanova.edu/proc2006/schwartz.pdf. Diakses pada tanggal 18 Oktober 2008.

Smith, K.J., Ervin, D. \& Davi, J.A., An examination of the antecedents of cheating among finance students. Journal of financial Education, Summer, 13-33, 2003.

Taylor, K. R., Cheater, cheater. Principal Leadership, 8, 74-77, 2003.

Teixeira \& Rocha, Academic cheating in Austria, Portugal, Romania and Spain: A comparative analysis. Research in Comparative and International Education, 1, 198-208, 2006.

Teodorescu, D. \& Andrei, T., Faculty and peers influences on academic integrity: College cheating in Romania. Journal of Higher education, 3, 1-12, 2008.

Tibbets, S. \& Herz, D., Gender Differences in factors of social control and rational choice. Deviant Behavior, 17, 183-208, 1996.

Tibbetts, S. G., Differences between women and men regarding decisions to commit test cheating. Research in Higher Education, 40, 323-342, 1999.

Tim Penyusun Kamus Pusat Pembinaan dan Pengembangan Bahasa. Kamus Besar Bahasa Indonesia. Jakarta: Balai Pustaka, 1994.

Thornberg, H.D., Development in Adolesence. California: Wadsworth, 1982.

Thorpe, M.F., Pittenger, D.J. \& Reed, B.D., Cheating the researcher: A study of the relationship between personality measures and self-reported cheating-statistical data included. College Student Journal, Maret, 1-11, 1999. 
Vandehey, M., Diekhoff, G.M., \& Labeff, E.E., College cheating: A twenty-years follow up and the addition of an honor code. Journal of college Students Development, 8, 2007.

Venezia, C. C., Are female accountants more ethical than male accountants: A comparative study between the U.S and Taiwan. International Business EEconomics Research Journal, 7, 1-10, 2008.

Witley, B.E., Factors associated with cheating among college student: A review. Research in Higher Education, 39, 235-274, 1998.

Witley, Jr., Nelson, A.B., \& Jones, C.J., Genderdifferences in cheating attitudes and classroom cheating behavior: A meta-analysis. Sex Roles: A Journal Research, 10, 1-20, 1999.

Zulle, L.B., Azman, J., Frkovic, V. \& Petrovecki M., Is there an effective approach to deterring students from plagiarizing? Science Engineering Ethics, 14, 193-147, 2008. 